\title{
The true poetry of life
}

Previously published at www.cmaj.ca

Osler's Bedside Library: Great Writers Who Inspired a Great Physician

Michael A. LaCombe, David J. Elpern, eds. American College of Physicians, 2010.

$O$ sler's Bedside Library is not directly about bedsides in the familiar medical sense. It is not intended for ailing patients, or reconciling the elderly to the dying of the light. Instead this book is meant for the bedside of young and vigorous students of medicine. Interns. And physicians beginning their careers.

It all goes back to an idea of that eminent Victorian doctor, Sir William Osler, who wanted young medical people to read not just what is called "medical literature," but literature of a more general and grander stamp. The Bedside Library is not concerned with that useful, but oppressive, flood of ephemeral reports and studies that weighs physicians down the more it keeps them up to date. It points to reading of a kind that might restore a sense of balance to minds overwhelmed by the routine of practice and the treadmill of keeping up. To quote the subtitle, it is about "great writers who inspired a great physician." It honours the wish of Sir William Osler that the great writers of history could somehow be allowed to teach physicians how to read those walking, breathing and infinitely mysterious books that are their patients.

"Nothing will sustain you more," Osler says in an essay on student life, "than the power to recognize in your humdrum routine, as perhaps it may be thought, the true poetry of life." But can a doctor who knows no poetry recognize the poetry of life?

Medicine is learned at the bedside, Osler believes, more than in the classroom, but to learn from seeing the sick, a doctor must first be able to see. Great literature teaches us to see. One of the contributors to this book says of the novelist

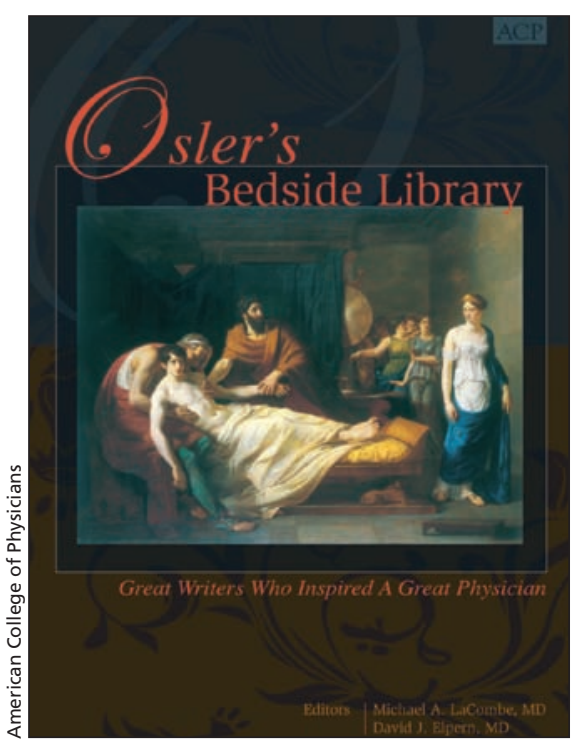

George Eliot that she "sets her characters with all their uniqueness of traits and doubts and actions and dreams, within the relentless current of the society that shaped them." A doctor who cannot appreciate these dimensions in a patient's life will sit at the bedside in vain.

Each of the 30 essays in this book deals with either a significant work of literature or writer of importance to Osler. The focal point is a list of 10 that Osler himself recommended to physicians in 1904. The remaining 20 concern books or authors who were part of Osler's vast reading and figured in his magnificent library that came as a bequest to McGill University in 1929. Poets, philosophers, novelists, and dramatists figure there, and the Bible too, which occupied first place on Osler's original list.

Osler was hardly the only Victorian big shot to have the idea that reading great literature was important. Everyone who mattered in that age agreed with Matthew Arnold that a life spent in ignorance of "the best that has been thought or said" was not worth living. "Taste is only to be educated by contemplation not of the tolerably good, but of the truly excellent," says Augustine Birrell, chief secretary for Ireland at the dawn of the 20th century. "Reading is not an expensive nor an unreachable pleasure, adds the Victorian bookman Sir William Roberston Nicoll. "It is within the power of all."

In the same year that Osler published his list for The Bedside Library, the British publisher J.M. Dent laid his plans to launch the Everyman series that would make the world's classic literature affordable for everyone.

How then to explain the fact that Osler transcends the age to which these other Victorians are confined? Osler's literary counsel is still sought. He still has readers and admirers like the three dozen contributors to this book who have put together a new Bedside Library for the physicians of their own time. Osler's surprising longevity must surely have to do with the special relevance of literature to the practice of medicine. There must be a need for constant vigilance to offset the gravitational attraction of mere technique, the perennial temptation to see the patient as a defective machine in need of fixing rather than compassionate healing. "The medical man, perhaps more than any other man," Osler warns, "needs that higher education of which Plato speaks."

Osler recognized that few doctors can become scholars. And he didn't think they ought to try. A doctor's life is "well filled with appointed tasks." But everyone can read for half an hour before going to sleep, and the profit of developing that habit will be a hundredfold, if the reading is chosen well. The new Bedside Library may not be a perfect selection. But a busy doctor whose life is contracting into a narrow routine will find in its pages winsome invitations to join a wider world.

\section{Graeme Hunter PhD \\ Professor}

Department of Philosophy

University of Ottawa

Ottawa, Ont.

Graeme Hunter lectures on literature at the summer conference for physicians at Augustine College, Ottawa, Ont. 